\title{
DOE/mT/950/0-
}

\section{Slag Characterization and Removal Using Pulse Detonation for Coal Gasification}

\author{
Quarterly Report \\ October 1 - December 31, 1996 \\ By:
Ziaul Huque; Daniel Mei
Paul O. Biney; Jianren Zhou
By:
Ziaul Huque; Daniel Mei
By:
Ziaul Huque; Daniel Mei
aul O. Biney; Jianren Zhou

RECFIVEO

mine 101998 


\section{Disclaimer}

This report was prepared as an account of work sponsored by an agency of the United States Government. Neither the United States Government nor any agency thereof, nor any of their employees, makes any warranty, express or implied, or assumes any legal liability or responsibility for the accuracy, completeness, or usefulness of any information, apparatus, product, or process disclosed, or represents that its use would not infringe privately owed rights. Reference herein to any specific commercial product, process, or service by trade name, trademark, manufacturer, or otherwise does not necessarily constitute or imply its endorsement, recommendation, or favoring by the United States Government or any agency thereof. The views and opinions of authors expressed herein do not necessarily state or reflect those of the United States Government or any agency thereof. 


\section{DISCLAIMER}

Portions of this document may be illegible electronic image products. Images are produced from the best available original document. 


\section{ECONOMIC FEASIBILTTY STUDY FOR PULSE DETONATION ENGINE installed in a mid large size boiler (400-600 MW boiler) are as follows:}

The economic feasibility study rcpiort was written and submitted to Document Control Center and Anthony E. Mayne (Contracting Officer's Representative) in a previous quarterly (reporting period: 10/01/96-12/31/96). Later, we were told to rewrite the report based on the design and unit cost. Also, we were asked to provide the background information based on which we had written the report. So, we contacted the North States Power (NSP) Company and those personnel who provided the necessary information.

\section{ECONOMIC ANALYSIS OF PULSE DETONATION ENGINE SOOT BLOWER INSTALLION}

This report is a preliminary economic analysis of the Sherburne Co. plant North Statc Power. This analysis is made with the cooperation of Joe Brojberg (senior analysis engineer of NSP) and Steve Bension (Slag and ash specialist, President of Microbeam Technologies Incorporated (MT) of North Dakota) and Paul Johnson of Diamond Power Speciality.

According to Paul Johnston, "Effective control of ash sccumulation through the boiler tubes costs big money by limiting the output of steam to the turbine and by requiring more fuel to make a pound of stesm. Typical savings on a mid to large size boiler can be as much as $\$ 3,000,000$ a year from steam output and $\$ 500,000$ for fuel". If we assurne the size of the plant to be $600 \mathrm{MW}$, then $5833 \$ / \mathrm{MW}$ are lost due to heat exchanger blockage. 
The Sherburne Co. plant consists of 3 units, a $800 \mathrm{MW}$ and two $750 \mathrm{MW}$ units (Total $2300 \mathrm{MW}$ ). The $800 \mathrm{MW}$ unit was recently taken off line for excessive ash build up in the heat exchanger unit in the convective pass. Evidently, the lead heat exchanger in the convective pass takes the burnt of the ash accumulation. In addition, the king unit of NSP, but not a part of Sherburne plant, had to be taken off line to clean the fouled heat exchangers which had "one foot accumulation of ash" according to Mr. Brojberg.

The $800 \mathrm{MW}$ unit was taken down for 4 days at $\$ 100,000$ per day, plus the cost of cleaning the unit which we estimate at $\$ 80,000$ for a total of $\$ 480,000$ $(4 \times 100,000+80,000)$. Assuming that the king unit downtime cost the same amount so that costs incurred at NSP due to fouling before the annual cleaning costs approximately $\$ 1,000,000$.

For this amount of money, 33 pulse detonation unit could be purchased $(1,000,000 / 30,000=33)$ where $\$ 25,000$ is the estimated cost for each PDE soot blower ( which resembles the steam units currently in use at NSP), and $\$ 5,000$ for installation. The PDE units will be retractable and will work about the same frequency as the current steam blowers now in use.

\section{COSTS}

The primary costs of the ash build up are as follows:

(1) downtime to clean unit before annual maintenance

(2) downtime cycles may be extended to 15 months instead of 12 months with detonation equipment

(3) loss of output of steam

(4) additional fuel to make a pound of steam

These costs will be estimated for the Sherburne plant of NSP only and will based on experience where possible. 
For Sherburne units, we will assume annual costs for taking down units for annual maintenance

Cost for 2, 750MW units $1500 \mathrm{MW} \times 600 \$ / \mathrm{MW}=\$ 900,000$

Cost per month 75,000

Maintenance cost per month of the $800 \mathrm{MW}$ unit required every 7 months 69,000 Annual maintenance for 3 plants/year $(69,000 \times 12+900,000)$ $1,728,000$

If this cycle can be extended to 15 months for all units due to PDE soot blowers, the following savings occur
without PDE for 15 months
$(75,000 \times 15+69,000 \times 15)$
$=\$ 2,160,000$
with PDE for 15 months
(2300MW X 600\$/MW)
$=1,380,000$
Savings for 15 months
780,000
Savings per month
52,000

This savings will allow to be purchased 21 PDE soot blowers $(780,000 / 30,000=21)$ per year.

If we book keep the lost efficiency in terms of dollar amounts due to slag and ash fouling, for the Sherburne plant at $5800 \$ / M W X 2300 \mathrm{MW}=\$ 13,340 \mathrm{~K}$. The Sherburne plant consumes $7,500 \mathrm{~K}$ tons of coal per year at a cost of $\$ 130,000 \mathrm{~K}$ in its present status. On an environmental basis, if $1-2 \%$ of the coal was saved to produce the same amount of power, $150 \mathrm{~K}$ tons of coal produces approximately $500 \mathrm{~K}$ tons of carbon dioxide, which could be prevented from entering the atmosphere. Taken world wide, the environmental savings will be enormous. 